\section{Revision of ICRP report on reference man}

SIR, In 1975 the International Commission on Radiological Protection (ICRP) published its publication 23, the Report of the task group on reference man. That report, with cited references ending in about 1970 , is out of date and is currently being revised. The revision will include more emphasis on variations due to age, sex, and other individual differences in anatomical and physiological data and in gross and elemental composition of tissues. The emphasis in ICRP 23 is on data for radiation workers, and the new emphasis reflects the fact that radiation doses to the whole population are of increasing interest to ICRP and national bodies interested in radiation protection.

I have responsibility for updating the chapter of ICRP publication 23 relating to the eye. I would value comments from users of ICRP 23 who have found errors, omissions, or general shortcomings in the previous treatment of this topic. Any new published data which are considered relevant should be sent to me at the address below. The emphasis of concern in radiological protection relates to radiation induced visual impairment, primarily through cataract induction. While general contributions are encouraged, those relating to radiation effects are particularly welcomed. Ophthalmological data relating to the morphology of the anterior of the eye, the morphology of the iris, and its uptake of radioactive materials, to mention just three examples, are areas where recent contributions in journals such as this will prove useful in directing radiological protection guidelines.

Radiobiology Laboratory, M W CHARLES

Berkeley Nuclear Laboratories,

Berkeley,

Gloucestershire

GL13 9PB

\section{Obituary}

\section{Surgeon Rear-Admiral D P Gurd, $C B, D S c, M D, M C L, F R C S, F R A C S$}

Surgeon Rear-Admiral Dudley Plunkett Gurd died on 9 August 1987 in an Italian hospital at the age of 77 as the result of a motor accident. He entered the Royal Navy as a surgeon lieutenant in 1934. In 1943 he was awarded the Gilbert Blane medal for services to naval medicine.

In 1952 he was seconded to St John Ophthalmic Hospital as warden, a post he held for three years during a most difficult time in the hospital's history when it was housed in three separate buildings in the old walled city of Jerusalem.
His hard work in most trying conditions was rewarded by the Queen in the form of a knighthood of the Most Venerable Order of the Hospital of St John of Jerusalem. He served in naval hospitals in Malta, Barrow Gurney, Hong-Kong, Plymouth, and Haslar. He ended his naval career as surgeon rear-admiral and medical officer in charge of RN Hospital, Bighi, until 1966, when he took up private practice as an ophthalmologist.

Dudley kept in touch by letter with many colleagues with whom he had served during his long period as a naval officer. He had a great love of the Royal Naval Medical Service, as witness his many articles in the Royal Naval Medical Gazette. He was a dedicated ophthalmic surgeon and kept his knowledge upto date in this rapidly changing speciality. His years with the Order of St John in Jerusalem gave him confidence with the scalpel in the operating theatre, and he was ever grateful for the opportunity in midcareer to serve a demanding surgical apprenticeship and acquire the skills so necessary for competent practice in the most precise of all surgical disciplines. He was a happy and fulfilled individual and so was able to impart a warmth to his chatter with the young and the old with kindly words enriched by his soft and attractive Ulster accent.

$\mathrm{He}$ is survived by his wife Thérèsa Marie and his son and daughter, whose sadness is shared by his many admirers.

SJHM

\section{Note}

\section{Research grants}

The David Cole Travel fellowship, instituted by Merck Sharp and Dohme in memory of Professor David Cole, will assist a visit to a hospital or research centre during the academic year starting 1 October 1988 . The award will be equivalent to $£ 2000$. The purpose of the award is to enable the successful applicant to gain experience and knowledge in pursuit of a specific project related to glaucoma.

The Glaucoma Group Research grant, sponsored by the International Glaucoma Association, will be available for a research project clinically orientated to glaucoma for 1988 . The award will be equivalent to $£ 2500$. The grant may be used towards salary or project expenses or for buying equipment.

Both these awards are available to medical graduates and non-medical scientists resident in the United Kingdom or the Irish Republic. They may be held concurrently with other awards. Further details and application forms from Dr S Nagasubramanian, Secretary Glaucoma Group, Glaucoma Unit, Moorfields Eye Hospital, High Holborn, London WC1V 7AN. The closing date for applications is 15 June 1988. The successful candidate will be informed by August 1988. 